\title{
Identifikasi Gaya Belajar Statistika Mahasiswa Pendidikan Matematika di Papua (Survei: Kota Jayapura)
}

\author{
Riska Yulianti' ${ }^{1}$ Elsi Sirampun², Andi Miftahul Maulidil Mursyid ${ }^{3}$, \\ Nur'im Septi Lestari ${ }^{4}$ \\ ${ }^{1,3,4}$ IAIN Fattahul Muluk Papua, ${ }^{2}$ Universitas Cenderawasih \\ yuliantiriska3031@gmail.com, sirampunelsi92@gmail.com, andi@iainfmpapua.ac.id, \\ nurimsepti@gmail.com
}

\begin{abstract}
Abstrak: Papua merupakan salah satu provinsi yang berada di paling timur Indonesia. Hal tersebut berdampak pada perkembangan Pendidikan terutama kemampuan akademik mahasiswa berkaitan dengan statistika. Selain dari letak geografisnya, terdapat factor lain yang mempengaruhi kemampuan akademik tersebut salah satunya factor internal yakni gaya belajar statistika yang terdiri dari gaya belajar visual, audio dan kinestetik (VAK). Survei gaya belajar dilakukan pada perguruan tinggi negeri yang terletak kota jayapura yaitu institute agama islam negeri (IAIN) Fattahul Muluk Papua dan Universitas Cenderawasih. Hasil dari survei menunjukkan bahwa mahasiswa Pendidikan matematika memiliki kecenderungan pada gaya belajar audio. Hasil tersebut didasarkan pada perolehan nilai mean mahasiswa IAIN FM sebesar 15,65 dan mahasiswa UNCEN sebesar 16,74. Keduanya memiliki nilai mean yang masuk dalam kategori tinggi.
\end{abstract}

Kata Kunci: Gaya belajar statistika; mahasiwa Pendidikan matematika

Abstract: Papua is one of the most eastern provinces in Indonesia. This has an impact on the development of education, especially students' academic abilities related to statistics. Apart from its geographical location, other factors influence academic ability one of which is the internal factor namely the statistics learning style which consists of visual, audio, and kinesthetic learning styles (VAK). The learning style survey was conducted at state universities located in Jayapura, namely the State Islamic Institute (IAIN) Fattahul Muluk Papua and Cenderawasih University. The results of the survey indicate that mathematics education students tend towards audio learning styles. These results are based on the acquisition of the mean score of IAIN FM students of 15.65 and UNCEN students of 16.74. Both have a mean value that is included in the high category.

Keywords: statistical learning style; mathematics education student

\section{Pendahuluan}

Indonesia termasuk salah satu negara kepulauan terbesar dengan 34 Provinsi didalamnya. Dari segi geografis, Papua merupakan salah satu provinsi yang terletak dipaling timur Indonesia. Hal ini berakibat pada perkembangan pendidikannya yang menjadi sedikit lebih lamban dibandingkan provinsi lainnya. Selain dari letak geografisnya, terdapat faktor lain yang mempengaruhi hal tersebut yakni meluasnya dampak dari covid-19. Data dari gugus covid-19 provinsi Papua sampai dengan 25 November 2020 menyatakan bahwa terdapat 11.481 orang terkonfimasi covid-19 dengan persentase $22 \%$ dirawat, $76 \%$ sembuh, dan $2 \%$ meninggal dunia. Guna mengatasi kesenjangan pendidikan yang diakibatkan oleh faktor tersebut di atas maka perlu adanya upaya serius. Bentuk implementasi dari upaya tersebut salah satunya adalah peningkatan kemampuan akademik mahasiswa di Papua.

Kemampuan akademik mahasiswa sendiri dipengaruhi oleh dua faktor penting yang terdiri dari factor eksternal dan factor internal. Factor eksternal merupakan factor yang berasal dari luar seperti perlu adanya sinergi kerjasama yang baik antar lembaga Pendidikan formal terkait yakni perguruan tinggi negeri (PTN). Adapun PTN yang dimaksud yaitu terdiri dari 
Institut Agama Islam Negeri (IAIN) Fattahul Muluk Papua dan Universitas Cenderawasih (UNCEN) yang terletak di Kota Jayapura. Keduanya memiliki berbagai program studi baik jenjang strata dua (S2) maupun strata satu (S1), salah satunya adalah Program studi strata satu (S1) Pendidikan Matematika atau Tadris Matematika. Program studi ini memiliki tujuan untuk memproses serta menghasilkan calon sarjana yang kompeten dibidang Pendidikan matematika. Dengan kata lain, mahasiswa diharapkan memiliki kemampuan akademik yang unggul terutama berkaitan dengan statistika.

Statistika merupakan salah satu cabang ilmu matematika selain daripada kalkulus, geometri, maupun aljabar (Quadratullah, 2014). Selain itu (Rahman, 2016) mengatakan statistika berhubungan dengan ilmu dalam mengolah dan menganalisis data. Pendapat lainnya dikemukakan oleh (Hilgers et al., 2018) yakni bidang ilmu yang mempelajari cara menyusun dan menyajikan data disebut statistika. Statistika sendiri merupakan salah satu cabang ilmu matematika yang berkaitan dengan data, (Ismail, 2018). Berdasarkan beberapa pendapat tersebut dapat disimpulkan bahwa statistika merupakan salah satu cabang ilmu matematika yang didalamnya membahas mengenai cara menyusun data, mengolah data, menganalisis data serta menyajikan data. Data tersebut kemudian dipaparkan dalam bentuk diagram ataupun tabel.

Selain factor eksternal di atas, terdapat juga factor internal yang mempengaruhi kemampuan akademik mahasiswa yakni motivasi belajar. Seperti yang diungkapkan, (Nurhidayah, 2015) yakni motivasi belajar memberikan dampak yang berbeda terhadap prestasi belajar matematika. Dengan kata lain, seorang siswa dengan prestasi belajar matematika tergolong tinggi cenderung memiliki motivasi belajar yang tinggi pula begitupun sebaliknya. Namun, (Barak et al., 2016) berpendapat bahwa motivasi belajar dikonseptualkan sebagai kecenderungan seseorang yang tergantung pada waktu ataupun konteks dalam menemukan kegiatan akademik sesuai dengan tujuan yang diinginkan. Implementasi dari kecenderungan tersebut biasanya di sebut gaya belajar.

Pada dasarnya, gaya belajar terbagi menjadi tiga bagian yaitu gaya belajar visual, audio, kinestetik yang biasa disebut gaya belajar VAK. Menurut (Khoeron et al., 2016), gaya belajar adalah cara yang digunakan seseorang dalam memahami sesuatu melalui panca indera. Pendapat lainnya dikemukakan oleh (Widayanti, 2013), gaya belajar merupakan cara seseorang dalam menyerap informasi secara maksimal. Setiap mahasiswa memiliki karateristik gaya belajar yang berbeda-beda, (Manolis et al., 2013). Hal ini dikarenakan tiap individu memiliki keunikannya masing-masing. Selain itu, (Mays, 2013) juga mengemukakan bahwa tujuan pendidikan mestinya sesuai dengan gaya belajar yang disukai oleh siswa maupun mahasiswa. Dengan kata lain dapat diartikan setiap mahasiswa memiliki cara berbeda dalam merespon, mengolah, dan menyimpulkan informasi secara maksimal. Hal ini diperkuat penelitian sebelumnya yang dilakukan oleh (Papilaya \& Huliselan, 2016) pada mahasiswa Bimbingan Konseling (BK) di Universitas Pattimura Ambon dan (Wahyuni, 2017) pada mahasiswa Pendidikan matematika Universitas bung hatta. Dengan demikian, gaya belajar VAK statistika merupakan salah satu factor penting dalam hal upaya meningkatkan kemampuan akademik mahasiswa sehingga perkembangan Pendidikan di Papua dapat menjadi lebih baik terutama dalam bidang Pendidikan matematika. Guna menjawab persoalan tersebut di atas, perlu dilakukan penelitian mendalam mengenai identifikasi gaya belajar VAK Statistika Mahasiswa Pendidikan Matematika di Papua.

\section{Metode penelitian}

Penelitian ini merupakan penelitian kuantitatif dengan metode survei dimana lebih menekankan pada pemilihan sampel yang representatif dari populasi tertentu. Populasi yang dimaksud sebanyak 492 mahasiswa Pendidikan matematika yang tersebar dibeberapa 
perguruan tinggi diwilayah Papua. Dengan jumlah lebih dari 100 orang, maka sampel yang diambil berkisar 10-25\% dari populasi (Arikunto, 2012). Pengambilan sampel dilakukan dengan menggunakan teknik purposive sampling. Sampel berasal dari IAIN Fattahul Muluk Papua dan Universitas Cenderawasih yakni berjumlah 73 mahasiswa Pendidikan matematika. Variabel dalam penelitian merupakan variabel tunggal yaitu gaya belajar VAK statistika. Instrument penelitian berupa angket gaya belajar berbentuk skala likert yang berjumlah 15 pernyataan positif. Pernyataan tersebut terdiri dari masing-masing 5 pernyataan berkaitan dengan gaya belajar VAK. Data yang diperoleh selanjutnya dianalisis menggunakan analisis statistik deskriptif. Menurut (Rahman, 2016) statistik destriktif merupakan salah satu bentuk analisis parametrik yang berfungsi memberikan gambaran data penelitian melalui diagram ataupun persentase.

\section{Hasil dan pembahasan}

Dalam penelitian ini, survei dilakukan pada perguruan tinggi negeri yang terletak di kota Jayapura dengan sampel penelitian yaitu seluruh mahasiswa Pendidikan matematika. Adapun mahasiswa yang telah memberikan tanggapan pada angket gaya belajar VAK statistika adalah sebagai berikut.

Table 1. Sebaran responden

\begin{tabular}{ccc} 
PTN & semester & Jumlah mhs \\
\hline & 2 & 14 \\
IAIN FM Papua & 4 & 8 \\
& 6 & 10 \\
& $\geq 8$ & 9 \\
\hline \multirow{2}{*}{ UNCEN } & 2 & 9 \\
& 4 & 7 \\
& 6 & 8 \\
& $\geq 8$ & 8 \\
\hline
\end{tabular}

Berdasarkan tabel 1 terlihat bahwa subjek penelitian yang terlibat berjumlah 73 mahasiswa yang tersebar dari 2 perguruan tinggi negeri (PTN) yaitu 41 orang mahasiswa berasal dari IAIN FM Papua dan 32 lainnya berasal dari UNCEN. Jumlah tersebut sesuai dengan (Arikunto, 2012), jika populasi lebih dari 100 orang maka sampel yang dapat diambil berkisar $10-25 \%$ dari jumlah populasi. Hal ini diperkuat oleh pendapat sebelumnya (Sugiyono, 2012) yang menyatakan bahwa penetuan sampel representatif dapat dilakukan dengan menggunakan rumus Slovin yaitu sebesar $10 \%$ dari populasi. Adapun sebaran responden tersebut kemudian diolah dalam bentuk persentase yang tertuang pada diagram lingkaran berikut.

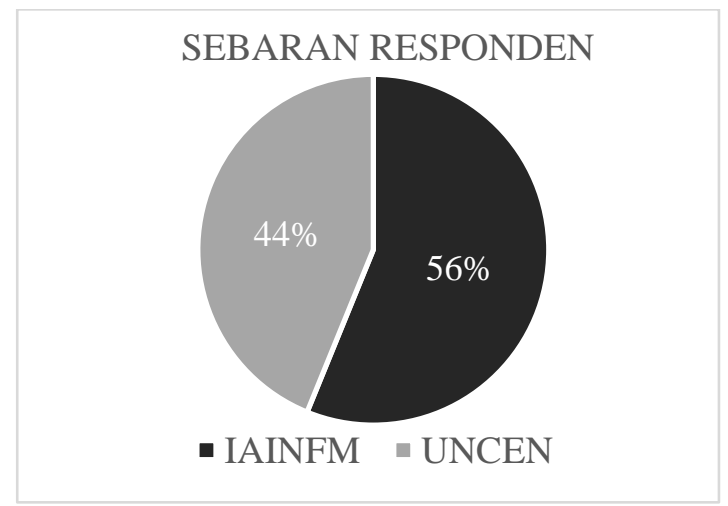

Gambar 1. Persentase keseluruhan 
Dari gambar 1 di atas terlihat bahwa 41 orang atau $56 \%$ merupakan mahasiswa IAIN FM Papua dan 32 orang atau 44\% adalah mahasiswa UNCEN. Persentase tersebut selanjutnya dipaparkan secara detail dalam bentuk rata-rata (mean) dari masing-masing gaya belajar statistika mahasiswa pada tiap semester dengan kategori sebagai berikut:

1. Tinggi jika nilai mean gaya belajar VAK statistika $\geq 13,33$

2. Sedang jika nilai mean gaya belajar VAK statistika $6,67<X<13,33$

3. Rendah jika nilai mean gaya belajar VAK statistika $\leq 6,67$

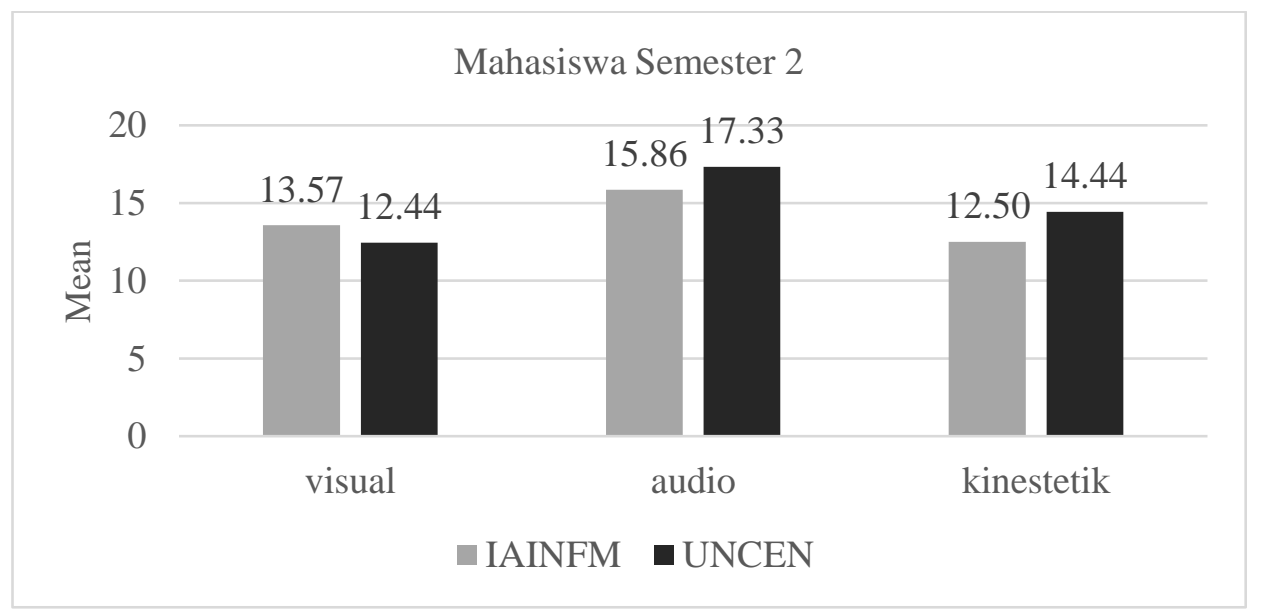

Gambar 2. Gaya belajar VAK semester 2

Pada gambar 2 terlihat mean gaya belajar visual dan audio termasuk dalam kategori tinggi yaitu sebesar 13,57 dan 15,86. Sedangkan mean gaya belajar kinestetiknya tergolong sedang yakni 12,50. Berdasarkan hasil tersebut dapat disimpulkan mahasiswa semester 2 IAIN FM Papua lebih dominan pada gaya belajar visual dan audio. Hasil berbeda justru ditunjukkan oleh mahasiswa UNCEN semester 2 yang mana gaya belajar visualnya tergolong sedang yaitu sebesar 12,44. Namun demikian, gaya belajar audio dan kinestetiknya tergolong tinggi dengan besaran rata-ratanya (mean) yakni 17,33 dan 14,44. Dengan kata lain, mahasiswa semester 2 UNCEN lebih dominan pada gaya belajar audio dan kinestetik.

Namun demikian, terlihat bahwa mahasiswa semester 2 dari IAIN FM Papua maupun UNCEN memiliki kecenderungan gaya belajar yang sama yaitu mean tertinggi terdapat pada gaya belajar audionya. Hal ini diperkuat oleh penelitian sebelumnya yang dilakukan oleh (Cimalla et al., 2011) di SMPN 2 Secanggang dengan hasil yakni hasil belajar fisika tertinggi di dominasi oleh siswa dengan gaya belajar auditorial. Dengan demikian dapat disimpulkan bahwa seorang pembelajar baik siswa maupun mahasiswa pada pembelajaran khususnya pelajaran eksak cenderung lebih banyak menggunakan gaya belajar audio dalam memahami serta mengolah informasi yang diperoleh. 


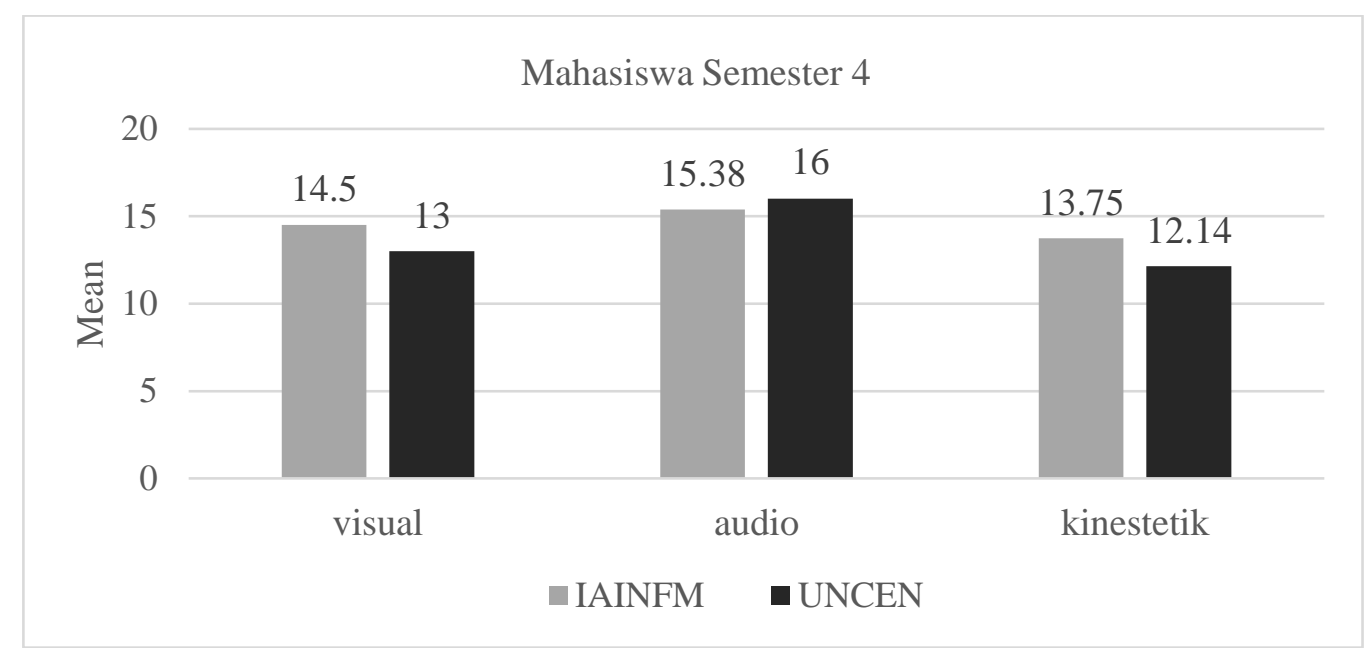

Gambar 3. Gaya belajar VAK semester 4

Berdasarkan gambar 3 terlihat bahwa nilai mean dari masing-masing gaya belajar untuk mahasiswa semester 4 IAIN FM Papua tergolong tinggi. Hal ini menunjukkan bahwa proses pembelajaran mata kuliah statistika di IAIN FM Papua dapat mengembangkan gaya belajar VAK dari setiap mahasiswa yang tentunya memiliki karakteristik berbeda. Namun demikian, hal berbeda justru ditunjukkan oleh mahasiswa UNCEN yang lebih cenderung pada gaya belajar audio saja yakni dengan mean sebesar 16,00. Sedangkan gaya belajar visual maupun kinestetiknya berada dalam kategori sedang yakni sebesar 13 dan 12,14. Dengan kata lain, proses pembelajaran mata kuliah statistika di UNCEN lebih menunjang untuk mahasiswa dengan gaya belajar audio saja. Hasil tersebut diperkuat penelitian sebelumnya yang dilakukan oleh (Klašnja-Milićević et al., 2011) dengan hasil penelitian yakni kegiatan pembelajaran haruslah didasarkan pada gaya belajar, pengetahuan dan kesukaan peserta didiknya.

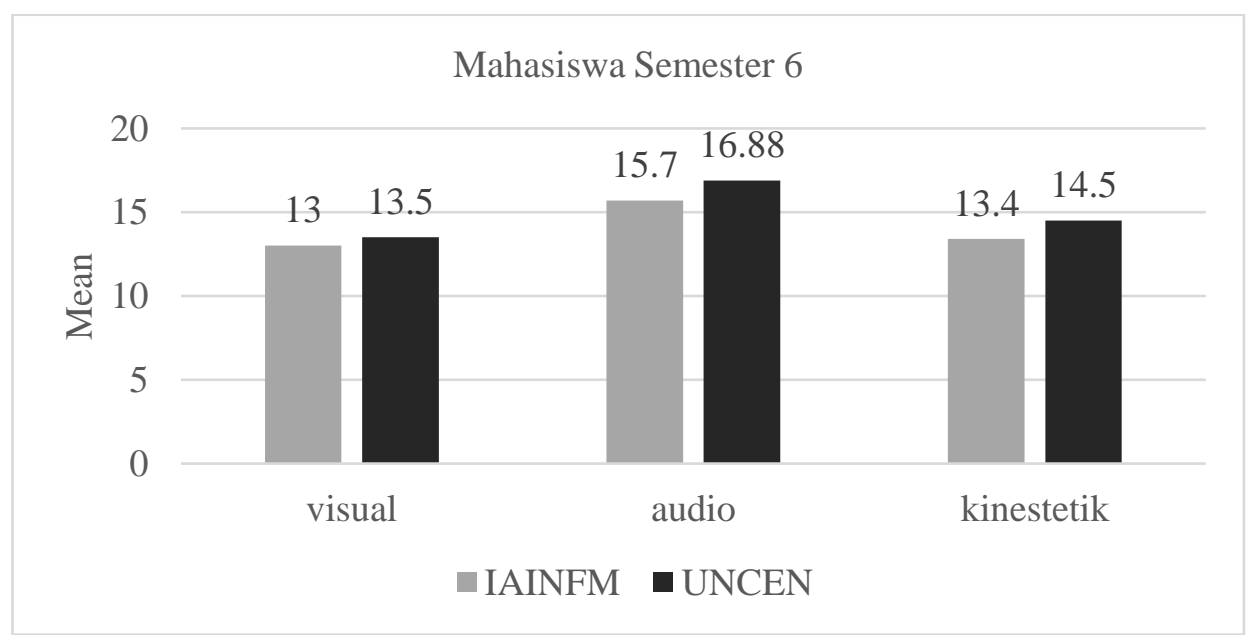

Gambar 4. Gaya belajar VAK semester 6

Hal sebaliknya ditunjukkan oleh mahasiswa semester 6 UNCEN dengan hasil dari masing-masing gaya belajar tergolong tinggi. Besaran nilai mean terdiri dari gaya belajar visual sebesar 13,3; gaya belajar audio sebesar 16,88; dan gaya belajar kinestetik sebesar 14,5. Hasil tersebut menunjukkan bahwa proses pembelajaran mata kuliah statistika di UNCEN dapat mengembangkan gaya belajar VAK dari setiap mahasiswa yang tentunya memiliki karakteristik berbeda. Sedangkan untuk mahasiswa IAIN FM Papua lebih cenderung pada gaya belajar audio dan kinestetik saja. Hal tersebut didasarkan pada nilai mean gaya belajar audio sebesar 15,7 dan mean gaya belajar kinestetik sebesar 13,4. Adapun untuk gaya belajar visualnya termasuk dalam kategori sedang dengan perolehan mean sebesar 13. Hasil tersebut 
dapat digunakan dalam mengembangkan proses pembelajaran matematika yang disesuaikan dengan gaya belajar mahasiswa. Hal ini sejalan dengan (Wibowo, 2016) yang menyatakan bahwa data gaya belajar dapat dimanfaatkan guna pengembangan materi ajar dan keaktifan mahasiswa dalam pembelajaran.

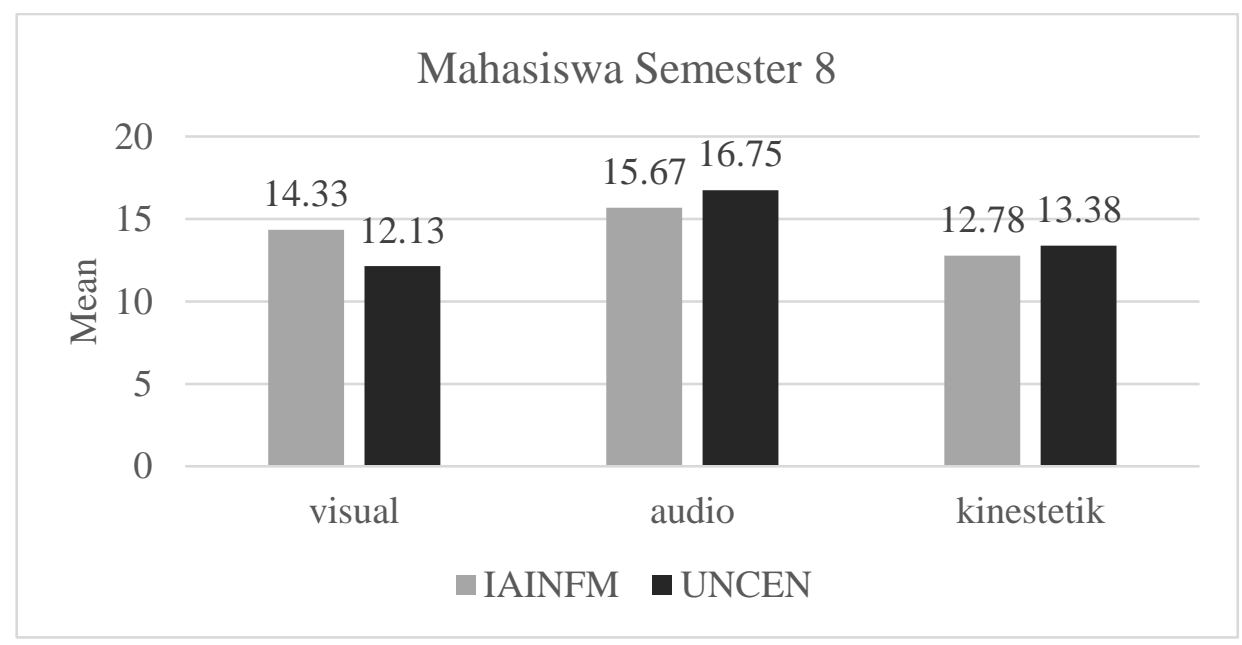

Gambar 5. Gaya belajar VAK semester 8

Adapun pada mahasiswa matematika semester 8, masing-masing perguruan tinggi memiliki kecendurungan gaya belajar yang berbeda. Hal tersebut dapat terlihat dari gambar 5, dengan hasil sebagai berikut:

1. Pada mahasiswa IAIN FM Papua lebih cenderung pada gaya belajar visual dan audio. Kedua gaya belajar tersebut tergolong dalam kategori tinggi dengan nilai mean sebesar 14,33 dan 15,67. Namun untuk gaya belajar kinestetiknya tergolong sedang yakni sebesar 12,78 .

2. Pada mahasiswa UNCEN lebih cenderung pada gaya belajar audio dan kinestetik yang termasuk dalam kategori tinggi. Dengan kata lain, nilai mean yang diperoleh keduanya $\geq$ 13,33 yaitu sebesar 16,75 dan 13,38. Sedangkan untuk gaya belajar visual sebesar 12,13 yang tergolong dalam kategori sedang.

Berdasarkan hasil di atas terlihat bahwa mahasiswa Pendidikan matematika memiliki gaya belajar statistika yang heterogen. Dengan hasil tersebut mengindikasikan bahwa pembelajaran statistika di semester 8 sebagian besar mahasiswanya banyak menggunakan gaya visual, audio maupun kinestetik. Hal ini sejalan dengan penelitian (Purmadi \& Surjono, 2016) yang mengatakan bahwa berdasarkan hasil survei dari 31 orang siswa SMA Negeri Sukamulia terlihat bahwa sebagian besar siswanya menggunakan gaya belajar heterogen dalam pembelajaran eksak khususnya mata pelajaran Fisika.

Namun demikian, jika hasil setiap gaya belajar VAK dari masing-masing semester diakumulasikan akan diperoleh hasil sebagai berikut. 


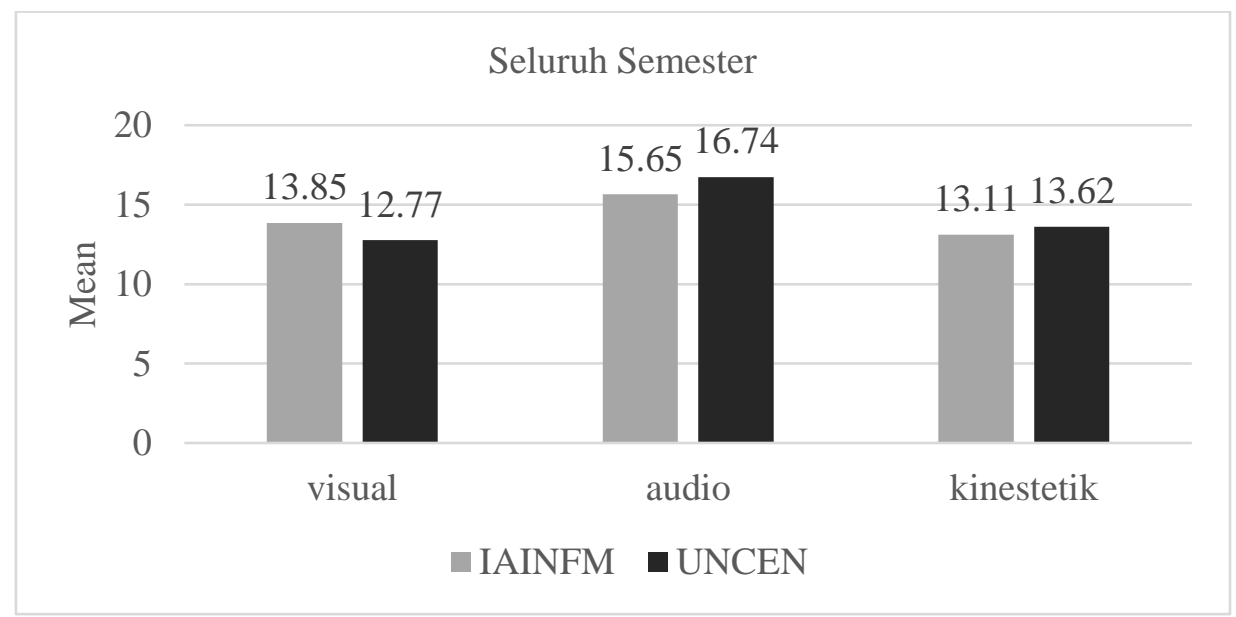

Gambar 6. Gaya belajar VAK seluruh semester

Berdasarkan gambar 6 di atas, masing-masing perguruan tinggi negeri memiliki mean gaya belajar VAK dari seluruh semester yaitu:

1. Mahasiswa IAIN FM memiliki kecendurangan gaya belajar visual dan audio yang tergolong tinggi yaitu sebesar 13,85 dan 15,65. Sedangkan gaya belajar kinestetiknya sebesar 13,11 yang tergolong sedang.

2. Lain halnya mahasiswa UNCEN yang lebih cenderung pada gaya belajar audio sebesar 16,74 dan gaya belajar kinestetik sebesar 13,62. Angka-angka tersebut termasuk dalam kategori tinggi. Namun untuk gaya belajar visual tergolong sedang yakni sebesar 12,77.

Berdasarkan perolehan tersebut terlihat bahwa mahasiswa baik IAIN FM maupun UNCEN memiliki kecenderungan gaya belajar yang berbeda. Perbedaan tersebut tentunya berpengaruh pada proses pembelajaran dan hasil belajar dari masing-masing mahasiswanya. Hal ini sejalan dengan penelitian (Permana, 2016) yang hasil penelitiannya menunjukkan terdapat pengaruh gaya belajar terhadap kemampuan belajar ilmu alamiah dasar pada mahasiswa program studi Pendidikan Bahasa Indonesia Universitas Indraprasta. Namun demikian, mahasiswa dari masing-masing PTN terlihat memiliki kecenderungan lebih dari satu gaya belajar yang biasa disebut dengan gaya belajar multimodal. Hasil di atas diperkuat oleh pendapat (PAYAPROM \& PAYAPROM, 2020) dalam penelitiannya yang mengemukakan bahwa 64\% mahasiswa program Bahasa di Universitas Chiang Rai Rajabhat Thailand memiliki gaya belajar multimodal.

Lain halnya jika dilakukan akumulasi gaya belajar VAK seluruh mahasiswa dari masingmasing perguruan tinggi negeri seperti pada gambar 7 berikut.

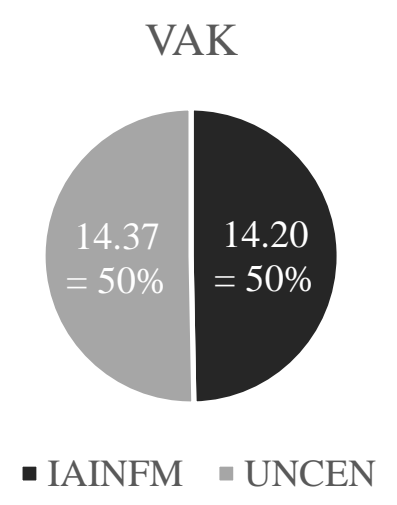

Gambar 7. Akumulasi gaya belajar VAK seluruh mahasiswa

Secara persentase, akumulasi ketiga gaya belajar dari seluruh mahasiswa menunjukkan besaran nilai 50\%. Hal ini dapat terlihat dari gambar 7 di atas yang mana mahasiswa IAIN FM 
Papua dan mahasiswa UNCEN memiliki gaya belajar VAK yang tergolong tinggi. Dengan kata lain, besaran persentase tersebut mengindikasikan bahwa mahasiswa dari kedua perguruan tinggi tersebut memiliki keselarasan gaya belajar terutama dalam hal kemandirian maupun pemecahan masalah. Hasil tersebut sejalan dengan penelitian sebelumnya yang dilakukan oleh (Sundayana, 2018) yakni gaya belajar siswa tidak berpengaruh terhadap kemandirian maupun pemecahan masalah matematis siswa. Hal yang sama diungkapkan (Widharyanto \& Binawan, 2020) bahwa siswa etnis papua memiliki gaya belajar utama yaitu gaya belajar aural atau yang biasa disebut gaya belajar audio.

\section{Kesimpulan dan Saran}

Gaya belajar merupakan salah satu factor penting dalam upaya peningkatan kemampuan akademik mahasiswa pendidikan matematika di wilayah Papua. Dalam hal ini gaya belajar yang di maksud adalah gaya belajar statistika yang terdiri dari gaya belajar visual, audio dan kinestetik (VAK). Survei dilakukan pada mahasiswa IAIN Fattahul Muluk Papua (IAIN FM) maupun Universitas Cenderawasih (UNCEN) guna mengidentifikasi dan menganalisis gaya belajar VAK dengan menggunakan analisis statistic deskriptif. Berdasarkan nilai mean, hasil yang diperoleh dari tiap semesternya yakni mahasiswa memiliki kecenderungan pada gaya belajar audio dengan akumulasi nilai yaitu 15,65 mahasiswa IAIN FM dan 16,74 mahasiswa UNCEN. Nilai tersebut menunjukkan bahwa keduanya memiliki gaya belajar audio yang tergolong dalam kategori tinggi. Adapun akumulasi gaya belajar visualnya yaitu untuk mahasiswa IAIN FM sebesar 13,85 dan mahasiswa UNCEN sebesar 12,77. Sedangkan hasil akumulasi gaya belajar kinestetik yakni 13,11 mahasiswa IAIN FM dan 13,62 mahasiswa UNCEN. Namun demikian, jika diakumulasikan seluruh gaya belajar VAK diperoleh hasil mean sebesar 14,37 mahasiswa IAIN FM dan 14,20 mahasiswa UNCEN yang mana secara persentase memiliki besaran sama yakni sebesar $50 \%$.

Hasil penelitian ini nantinya dapat dijadikan rujukan berbagai pihak yang terkait dalam proses pembelajaran statistika perguruan tinggi terutama di wilayah Papua. Selain itu, pembelajaran yang terjadi mesti didasarkan pada gaya belajar mahasiswanya baik visual, audio maupun kinestetik sehingga terdapat peningkatan kemampuan akademik mahasiswa tersebut. Dalam penelitian ini terdapat beberapa keterbatasan, salah satunya adalah persoalan yang dikaji hanya terbatas pada mengidentifikasi dan menganalisis gaya belajar dengan menggunakan statistic deskriptif sehingga hasil penelitian yang diperoleh hanya berupa gambaran gaya belajar dalam bentuk nilai mean maupun persentase yang disajikan dalam diagram. Oleh karena itu, pada penelitian berikutnya diharapkan perlu mengkaji persoalan yang sama secara lebih dalam serta detail dengan menggunakan analisis statistic berbeda sehingga diperoleh hasil yang bervariatif. Selain itu, perlu dilakukan penelitian tidak hanya gaya belajar statistika namun gaya belajar pada mata kuliah lainnya.

\section{Daftar Pustaka}

Arikunto, S. (2012). Prosedur Penelitian. Jakarta: Rineka Cipta.

Barak, M., Watted, A., \& Haick, H. (2016). Motivation to learn in massive open online courses: Examining aspects of language and social engagement. Computers \& Education, 94, 4960. https://doi.org/10.1016/j.compedu.2015.11.010

Cimalla, P., Walther, J., Mittasch, M., \& Koch, E. (2011). Shear flow-induced optical inhomogeneity of blood assessed in vivo and in vitro by spectral domain optical coherence tomography in the $1.3 \mu \mathrm{m}$ wavelength range. Journal of Biomedical Optics, 16(11), 116020. https://doi.org/10.1117/1.3653235 
Hilgers, R.-D., Heussen, N., \& Stanzel, S. (2018). Statistik, deskriptive. In Lexikon der Medizinischen Laboratoriumsdiagnostik (pp. 1-1). Springer Berlin Heidelberg. https://doi.org/10.1007/978-3-662-49054-9_2900-1

Ismail, F. (2018). Statistika untuk penelitian pendidikan dan ilmu-ilmu sosial. In Prenadamedia Group.

Khoeron, I. R., Sumarna, N., \& Permana, T. (2016). PENGARUH GAYA BELAJAR TERHADAP PRESTASI BELAJAR PESERTA DIDIK PADA MATA PELAJARAN PRODUKTIF. Journal of Mechanical Engineering Education, 1(2), 291. https://doi.org/10.17509/jmee.v1i2.3816

Klašnja-Milićević, A., Vesin, B., Ivanović, M., \& Budimac, Z. (2011). E-Learning personalization based on hybrid recommendation strategy and learning style identification. Computers and Education. https://doi.org/10.1016/j.compedu.2010.11.001

Manolis, C., Burns, D. J., Assudani, R., \& Chinta, R. (2013). Assessing experiential learning styles: A methodological reconstruction and validation of the Kolb Learning Style Inventory. Learning and Individual Differences, 23, 44-52. https://doi.org/10.1016/j.lindif.2012.10.009

Mays, J. C. C. (2013). Matters of Style. In Coleridge's Experimental Poetics (pp. 67-95). Palgrave Macmillan US. https://doi.org/10.1057/9781137350237_4

Nurhidayah, D. A. (2015). Pengaruh Motivasi Berprestasi dan Gaya Belajar Terhadap Prestasi Belajar Siswa Pada Mata Pelajaran Matematika SMP. Jurnal Dimensi Pendidikan Dan Pembelajaran. https://doi.org/http://dx.doi.org/10.24269/dpp.v3i2.83

Papilaya, J. O., \& Huliselan, N. (2016). IDENTIFIKASI GAYA BELAJAR MAHASISWA. Jurnal Psikologi Undip. https://doi.org/10.14710/jpu.15.1.56-63

PAYAPROM, S., \& PAYAPROM, Y. (2020). Identifying learning styles of language learners: A useful step in moving towards the learner-centred approach. Dil ve Dilbilimi Çalışmaları Dergisi, 16(1), 59-72. https://doi.org/10.17263/j1ls.712646

Permana, A. (2016). Pengaruh Gaya Belajar dan Motivasi Belajar Mahasiswa Terhadap Kemampuan Belajar Ilmu Alamiah Dasar. Formatif: Jurnal Ilmiah Pendidikan MIPA, 6(3). https://doi.org/10.30998/formatif.v6i3.999

Purmadi, A., \& Surjono, H. D. (2016). PENGEMBANGAN BAHAN AJAR BERBASIS WEB BERDASARKAN GAYA BELAJAR SISWA UNTUK MATA PELAJARAN FISIKA. Jurnal Inovasi Teknologi Pendidikan, 3(2), 151. https://doi.org/10.21831/jitp.v3i2.8285

Quadratullah, M. F. (2014). • Statistika Terapan. Penerbit Andi Yogyakarta.

Rahman, Z. (2016). Pengantar Statistika. In Pengantar Statistika. Indonesia Prime. https://doi.org/10.14724/2002

Sugiyono. (2012). Quantitative Research Methods, Qualitative and R \& D. In Alfabeta.

Sundayana, R. (2018). Kaitan antara Gaya Belajar, Kemandirian Belajar, dan Kemampuan Pemecahan Masalah Siswa SMP dalam Pelajaran Matematika. Mosharafa: Jurnal Pendidikan Matematika. https://doi.org/10.31980/mosharafa.v5i2.262

Wahyuni, Y. (2017). IDENTIFIKASI GAYA BELAJAR (VISUAL, AUDITORIAL, KINESTETIK) MAHASISWA PENDIDIKAN MATEMATIKA UNIVERSITAS 
BUNG HATTA. Jurnal Penelitian Dan Pembelajaran Matematika, 10(2). https://doi.org/10.30870/jppm.v10i2.2037

Wibowo, N. (2016). UPAYA PENINGKATAN KEAKTIFAN SISWA MELALUI PEMBELAJARAN BERDASARKAN GAYA BELAJAR DI SMK NEGERI 1 SAPTOSARI. Elinvo (Electronics, Informatics, and Vocational Education). https://doi.org/10.21831/elinvo.v1i2.10621

Widayanti, F. D. (2013). PENTINGNYA MENGETAHUI GAYA BELAJAR SISWA DALAM KEGIATAN PEMBELAJARAN DI KELAS. Erudio Journal of Educational Innovation, 2(1). https://doi.org/10.18551/erudio.2-1.2

Widharyanto, B., \& Binawan, H. (2020). LEARNING STYLE AND LANGUAGE LEARNING STRATEGIES OF STUDENTS FROM VARIOUS ETHNICS IN INDONESIA. Jurnal Cakrawala Pendidikan, 39(2), 480-492. https://doi.org/10.21831/cp.v39i2.28173 